\title{
Sperm filtration as an alternative technique for seminal plasma separation in boars
}

\section{Filtração de ejaculados suínos como alternativa para a separação do plasma seminal}

\author{
Carlos Augusto Alves Melanda ${ }^{1}$; Ana Beatriz Marques de Almeida ${ }^{1}$; \\ Myrian Megumy Tsunokawa Hidalgo ${ }^{1}$; Anne Kemmer Souza'; Luiz Guilherme \\ Corsi Trautwein ${ }^{1}$; Jamile Haddad Neta ${ }^{1}$; Évelyn Rangel dos Santos ${ }^{1}$; \\ Antonio Cezar de Oliveira Dearo ${ }^{2}$; Maria Isabel Mello Martins ${ }^{2 *}$
}

\section{Highlights}

The sperm samples with seminal plasma showed better motility results.

Ejaculate centrifugation or filtration induced the sperm hyperactivation.

The presence of seminal plasma induced higher levels of lipid peroxidation.

The centrifuged and filtered sperm refrigerated for 48 hours reduced ROS production.

Sperm filtration is a valid method to replace the ejaculate centrifugation.

\begin{abstract}
The present study aimed to evaluate the filtration for separating seminal plasma of boars' ejaculate by means of sperm viability and the occurrence of hyperactivation and lipid peroxidation in fresh semen and after cooling for up to 96 hours. The ejaculate of eight healthy boars of different breeds was collected and the gelatinous portion was separated and discarded. In the laboratory, the semen was fractioned into three aliquots (groups G1, G2 and G3) as follows: G1: semen with plasma diluted in BTS (TOTAL BTS); G2: semen centrifuged at 600G/10' (BTS CEN); and G3: semen filtered with the Sperm-filter ${ }^{\circledast}$ following dilution of the retained cells with BTS (BTS FIL). The analyses were performed at three moments: with fresh samples (D0) and after 48 (D2) and 96 hours (D4) of cooling at $17^{\circ} \mathrm{C}$. The kinetic evaluation was performed using the CASA system, which provided data for the classification of sperm hyperactivity. For lipid stress analysis, the TBARS (thiobarbituric acid reactive substance) test was performed. The variance analysis test was conducted to compare the results between the groups and moments analyzed. The results showed better total motility values (\%) for $\mathrm{G} 1$ at $\mathrm{D} 0(67.9, \mathrm{P}=0.001), \mathrm{D} 2(36.6, \mathrm{P}=0.004)$ and $\mathrm{D} 4(26.1, \mathrm{P}=0.003)$. The occurrence of hyperactivity was observed in $\mathrm{G} 2$ and $\mathrm{G} 3$ at moments D2 and D4. In addition, TBARS showed higher peroxidation levels for $\mathrm{G} 1$ at $\mathrm{D} 0$ (8.1 $\mathrm{mM} \mathrm{MDA} / \mathrm{ml}, \mathrm{P}=0.01)$, D2 (7.4 mM MDA/ml, $\mathrm{P}=0.02)$,

1 Doctoral's Degree Students, Postgraduate Programe of Animal Science, Universidade Estadual de Londrina, UEL, Londrina PR, Brazil. E-mail: carlaomelanda@hotmail.com; biamarquesvet30@gmail.com; myrianhid@gmail.com; aks.kemmer@gmail.com; luiz@sintese.digital; jamilehaddad@yahoo.com.br; evelyn-rangel@hotmail.com

2 Profs. Drs., Graduate Programe of Veterinary Medicine, UEL, PR, Brazil. E-mail: dearoco@uel.br; imartins@uel.br

* Author for correspondence
\end{abstract}

Received: Oct. 19, 2020 - Approved: Apr. 07, 2021 
and D4 (6.41 mMol MDA $/ \mathrm{ml}, \mathrm{P}=0.008)$ when compared to $\mathrm{G} 2$ and $\mathrm{G} 3$. Since the filtration method did not demonstrate any damage to the sperm viability, the study concluded that sperm filtration is an accessible and valid tool to replace centrifugation.

Key words: Hyperactivity. Sperm-filter. Semen. Lipid peroxidation. Boar.

\section{Resumo}

O presente estudo objetivou avaliar a filtração como alternativa para a separação do plasma seminal de ejaculados suínos, ao considerar a viabilidade espermática por meio da ocorrência de hiperativação e peroxidação lipídica no sêmen fresco e após refrigeração por até 96 horas. O ejaculado, de oito cachaços saudáveis de diferentes raças, foram colhidos por meio da técnica da mão enluvada e porção gelatinosa foi separada e descartada. Em laboratório, o sêmen foi fracionado em três alíquotas (grupos G1, G2 e G3) da seguinte forma: G1: sêmen e plasma seminal, diluído em BTS (TOTAL BTS); G2: ejaculado centrifugado a 600G/10' para separação do plasma seminal, e o pellet de espermatozoides formados foram ressuspensos em BTS (BTS CEN); e G3: sêmen filtrado com Sperm-filter ${ }^{\circledR}$, e espermatozoides retidos foram diluídos em BTS (BTS FIL). As análises foram realizadas em três momentos: amostras frescas (D0), após 48 horas (D2) e seguidas 96 horas (D4) de refrigeração a $17^{\circ} \mathrm{C}$. A avaliação cinética foi realizada pelo sistema CASA, que forneceu dados para a classificação da hiperatividade espermática. Para análise de estresse lipídico, foi realizado o teste TBARS (substâncias reagente ao ácido barbitúrico). Um teste de análise de variâncias foi feito para detectar diferenças entre os grupos e momentos avaliados. Os resultados mostraram melhores valores de motilidade total (\%) para G1 em D0 (67,9, P= 0,001), D2 $(36,6, P=0,004)$ e D4 $(26,1, P=0,003)$. A ocorrência de hiperatividade foi observada em G2 e G3 nos momentos D2 e D4. Além disso, o TBARS mostrou níveis de peroxidação lipídica mais elevados para G1 em D0 (8,1 mM MDA / ml, P = 0,01), D2 (7,4 $\mathrm{mM}$ MDA/ml, $\mathrm{P}=0,02)$ e $\mathrm{D} 4(6,41 \mathrm{mMol} \mathrm{MDA} / \mathrm{ml}, \mathrm{P}=0,008)$ quando comparado com $\mathrm{G} 2$ e G3. Como a filtração não induziu a danos na viabilidade espermática, o estudo concluiu que a filtração espermática é uma ferramenta acessível e válida para substituir a centrifugação com intuito de separar o plasma seminal. Palavras-chave: Cachaço. Hiperatividade. Peroxidação lipídica. Sêmen. Sperm-filter.

\section{Introduction}

Seminal plasma plays an important role in the fertilization process by assisting the sperm transport through the female's reproductive tract and providing metabolic substrates to sperm cells, among other functions (Alkmin et al., 2014; Li, Roca, Pérez-Patiño, Barranco, \& Martinez, 2018). Notwithstanding, deleterious effects of seminal plasma have been demonstrated when in contact with sperm cells during semen refrigeration and freezing processes, such as membrane and acrosome damages (Alkmin et al., 2014; Li et al., 2018; Okazaki, Abe, Yoshida, \& Shimada, 2009; Pavaneli et al., 2019; PerezPatiño et al., 2016; Saravia et al., 2009).

Boar ejaculate has a large volume of seminal plasma and its removal is essential to adjust the sperm concentration (GómezFernández, Gómez-Izquierdo, Tomás, Mocé, \& Mercado, 2012). Moreover, extraction of seminal plasma minimizes its deleterious effect over the spermatozoa during sperm cryopreservation (Li et al., 2018). 
Due to its simple execution, centrifugation is a conventional method for removing seminal plasma. However, the equipment needed is considered expensive and a laboratory is required. In addition, the process can cause, early sperm hyperactivity membrane lesions, acrosome damage due to the eccentric force generated (Gadea, Martínez-Miró, Decuadro-Hansen, \& Matás, 2006; Hallap, Ha, Larsson, \& RodriguezMartinez, 2004; Ramires et al., 2013). Furthermore, the centrifugation process induces the production of ROS (oxygenreactive species) caused by the sperm excitation and the early capacitation (Aitken \& Clarkson, 1988).

Although sperm hyperactivation is a physiological mechanism of sperm capacitation, early hyperactivation induces energy loss and reduces the likelihood of fertilization. Evaluation of sperm kinetics in boar semen using the CASA system showed that a hyperactivated population demonstrates values of LIN (linearity) $<41 \%$, STR (straightness) $<60 \%$, ALH (lateral head amplitude) $>3 \mu \mathrm{m}$ and WOB (oscillation index) $<54 \%$, simultaneously (Pavaneli et al., 2019).

Small amounts of free radicals are necessary for sperm capacitation, hyperactivation and acrosomal reaction (Awda, Mackenzie-Bell, \& Buhr, 2009; Menegat etal., 2017). However, when ROS concentration exceed the threshold level, it becomes harmful (Nogueira et al., 2014), causing lipid membrane peroxidation and damage to membrane proteins, enzymes, carbohydrates and sperm cells DNA (Barreiros, David, \& David, 2006).

Due to the sperm changes caused by the removal of seminal plasma with the centrifugation technique, alternative techniques, such as the ejaculate filtration with a syntethic hydrofilic membrane, have been used in stallions (Alvarenga, Melo, Magalhães, \& Papa, 2010; Larentis, Camozzato, Bastos, Gregory, \& Mattos, 2018; Ramires et al., 2013), bulls (Campanholi et al., 2017) and buffaloes (Albuquerque et al., 2017). Nonetheless, the effect of this technique using the Spermfilter $^{\circledR}$, in intent to remove the seminal plasma in swine is unknown.

Therefore, the aim of this study was to evaluate the Sperm-filter ${ }^{\circledR}$ as a tool in the filtration of fresh ejaculate from boars by analyzing sperm viability and the occurrence of hyperactivation and lipid peroxidation, in fresh semen and after refrigeration for up to 96 hours, in comparison with the centrifuge method.

\section{Material and Methods}

The study was approved by the Universidade Estadual de Londrina Ethics Committee on the Use of Animals -CEUA / UEL number 19758.2017.56.

\section{Animals}

Ejaculates were obtained from eight (8) adult, healthy boars of five different breeds (Landrace $(n=1)$, Pietrain $(n=1)$, Large White $(n=1)$, Duroc $(n=2)$ and industrial crossed breeds (Agroceres blood line; $n=3$ )), with an average age of $24.37( \pm 9.72)$ months. All the boars were used for reproduction, and the sperm collections were performed once a week. 
Semen collection, division of groups, and sperm centrifugation and filtration

A single ejaculate from each boar was collected using the gloved hand technique (Hancock, 1959) with the boar mounted on a stationary dummy. The average volume of the ejaculates' volume was $575 \mathrm{ml}$, after collection, a $50 \mathrm{ml}$ aliquot was diluted 1:1 with Beltsville Thawing Solution (BTS) (Prolimax BTSE $^{\circledR}$ ) and transported for about 40 minutes, in a polystyrene box at room temperature, to the laboratory.

Each sample was divided into three aliquots BTS with total semen (G1), centrifuged (G2) and filtered (G3), and each one contained $30 \mathrm{~mL}$ of the ejaculate diluted in BTS.

For G2 samples, the semen was centrifuged at $600 \mathrm{G}$ for 10 minutes in a nonrefrigerated centrifuge as previous proposed by Ramires et al. (2013). Immediately after the centrifugation, the supernatant was discarded, and the pellet was resuspended in a 1:1 proportion of BTS.

For the G3 samples, the semen was filtered (Sperm Filter ${ }^{\circledR}$ BotuPharma/ Pat req. US2010/0099075, Botucatu, São Paulo, Brazil) following the manufacturer's instructions. Briefly, the ejaculate containing the seminal plasma (SP) was filtered by the Sperm-filter ${ }^{\circledR}$, and so the SP passed through the filter membrane, and the sperm cells was retained in the Sperm-filter ${ }^{\circledR}$. Subsequently, the spermatozoa retained in the filter were resuspended in BTS (1:1).

Each group was formed by eight repetitions, and the final concentration in all the groups was $50 \times 10^{6} \mathrm{sperm} / \mathrm{ml}$. The samples were evaluated at three moments: fresh (D0); after 48h (D2) and after 96h (D4) of refrigeration at $17^{\circ} \mathrm{C}$.

\section{Sperm kinetics}

The evaluation of sperm kinetics was performed at all moments (i.e. D0, D2 and D4), at room temperature $\left(24^{\circ} \mathrm{C}\right)$, using computerized analysis (Computer-assisted Sperm Analyzer, Hamilton-Thorne IVOS, Beverly, MA, USA, version 14.0) for the swine setup (parametersvalues: Frames Acquired- 30, Frame Rate $(\mathrm{Hz})$ - 60, Minimum Cell Size (Pixels) - 7, Minimum Static Contrast- 30, Straightness (STR) Threshold (\%) - 70, VAP cut-off ( $\mu \mathrm{m} / \mathrm{s})$ - 30, Prog. Min VAP $(\mu \mathrm{m} / \mathrm{s})-45, \mathrm{VSL}$ cut-off $(\mu \mathrm{m} /$ s) - 20). Kinetics parameters included: total motility (\% MT); progressive motility (\% MP); fast sperm (\% Rapid); travel speed ( $\mu \mathrm{m} / \mathrm{s}$ VAP); progressive speed ( $\mu \mathrm{m}$ / s VSL); curvilinear speed ( $\mu \mathrm{m} / \mathrm{s}$ VCL); lateral head amplitude ( $\mu \mathrm{m}$ ALH); straightness (\% STR), linearity (\% LIN) and oscillation (\% WOB).

Hyperactivated sperm behavior was determined according to Pavaneli et al. (2019) setting, considering the LIN <41\%, STR $<60 \%$, ALH $>3 \mu \mathrm{m}$ and WOB $<54 \%$ occurring simultaneously in the sperm samples average of each group, therefore a statistical analysis was not performed to identify the sperm hyperactivated pattern.

Lipid peroxidation analysis (Tbars thiobarbituric acid reactive substances)

The occurrence of lipid peroxidation and production of ROS was assessed using the adapted TBARS technique described by Placer, Cushman, \& Johnson (1966). Semen samples from each group were subjected to spontaneous (TBARS SP) and induced (TBARS SG) lipid peroxidation reactions and analyzed in a spectrophotometer (EVOLUTION 60S, UVvisible Spectrophotometer, ThermoScientific ${ }^{\circledR}$, 
Vantaa, Finland) with a wavelength of $532 \mathrm{~nm}$. The optical density obtained by the control samples in the spectrophotometry was tabulated in a worksheet to generated a standard curve. An equation was developed to which the optical density of the sperm samples was added to find the MDA concentrations. The results were expressed in $\mu \mathrm{mol}$ of MDA $/ \mathrm{ml}$.

\section{Statistical analysis}

The results from the semen samples were submitted to a Linear regression test, to evaluate whether the boar breed influenced the sperm parameters analyzed. The data were analyzed for the normally distribution using the Shapiro-Wilk test, and the Levene test was conducted to identify the homogenous distribution, the normality and the homogeneity was achieved when $p>0,05$. The results obtained from the sperm sample analysis were compared between groups (G1, G2 and G3) and between moments of refrigeration (D0, D2 and D4). The results of VAP, VSL and TBARS have not shown normality $(p<0,05)$ for the group analysis. For the moments evaluation, fast cells, STR, LIN, WOB and TBARS did not present normality $(p<0,05)$. The data from the groups considered normal $(p>0,05)$ were analyzed using ANOVA, and if any differences were identified between groups, the Tukey test was performed. Furthermore, the non-parametric $(p<0,05)$ samples were analyzed with the KruskallWallis test. To detect differences between the moments evaluated, it was performed the one-way repeated measures ANOVA, followed by the Tukey test if necessary, for the data with normal distributions. To the nonparametric data for moments, the Friedman test was conducted. The statistical analysis was conducted in the software Sigma Plot 11.0. The significance level was set at $5 \%$.

\section{Results and Discussion}

The boar breeds did not demonstrate any influence on the sperm kinetics results (MOT, $P=0,236$, MOTP $P=0,823$, Fast sperm $P=0,317$, VAP $p=0,249, V S L p=0,635, V C L$ $P=0,107, A L H \quad P=0,595, \quad B C F=0,076, \quad S T R$ $P=0,181$, LIN $P=0,953$, WOB $P=0,395)$ or the TBARS results (SP TBAR $P=0,727$, SG TBAR $\mathrm{p}=0,310$ ).

The sperm kinetics results from the three groups were summarized in Table 1. In fresh semen (D0), the total motility values $(p=0.001)$ and fast sperm $(p=0.007)$ of the total sperm group (G1) were higher than the centrifuged (G2) and filtered semen (G3), however, there was a difference only between the $\mathrm{G} 1$ and $\mathrm{G} 2$ groups in progressive motility $(p=0.019)$. The variables VAP, VCL and ALH did not differ between the groups studied neither among the period of refrigeration. There was a significant reduction in sperm motility after 48 and 96 hours of refrigeration for the total group, centrifuged and filtered ( $p$ $<0.05$ ). The same phenomenon was observed for progressive motility and percentage of fast sperms in all evaluated groups. The VSL parameter only showed a reduction at 96 hours after refrigeration, while the STR had its percentage decreased after 48 hours.

Sperm hyperactivation was evaluated following the patterns set by Pavaneli et al. (2019). Sperm hyperactivation did not occur in any fresh ejaculate (DO) group. However, hyperactivated sperm were observed in both G2 (centrifuged) and G3 (filtered) after 48 (D2) and 96 (D4) hours of refrigeration (Table 1). 
The lipid peroxidation levels were expressed as MDA concentrations, as it is shown in Table 2. The highest rate of lipid peroxidation (TBARS) occurred in G1 (Total) at the three moments evaluated (D0 $(P=0.01)$ D2 $(P=0.002)$ and D4 $(P=0.008))$. However, refrigeration did not interfere with the production of ROS.

The results of this study showed values of total and progressive motility similar to another porcine study that used the same CASA system setup (Souza et al., 2013).
However, differences between the CASA system set up for the same species, may induce to different results for the sperm path analysis. In the study performed by Menegat et al. (2017), the sperm cells refrigerated for up to 168 hours using the same diluent (BTS), showed numerically higher values for the parameters evaluated by the CASA system, possibly due to the less stricter setup criterion used. Therefore, it is relevant to emphasize the importance of standardizing the set up for all the CASA systems.

\section{Table 1}

Kinetics evaluation results of boars' ejaculate using the CASA system. Total semen samples (G1), centrifuged at $600 \mathrm{~g} / 10 \mathrm{~min}$ (G2) and filtered through Sperm filter ${ }^{\circledast}$ (G3) at three moments: fresh (D0) and refrigerated for $48 \mathrm{~h}(\mathrm{D} 2)$ and $96 \mathrm{~h}$ (D4) at $17^{\circ} \mathrm{C}$

\begin{tabular}{|c|c|c|c|c|c|c|c|c|}
\hline \multirow{2}{*}{$\begin{array}{c}\text { Kinetic } \\
\text { Parameter }\end{array}$} & \multirow[b]{2}{*}{ Moment } & \multicolumn{2}{|c|}{ Total (G1) } & \multicolumn{2}{|c|}{ Centrifuged (G2) } & \multicolumn{2}{|c|}{ Filtered (G3) } & \multirow[b]{2}{*}{ P-value } \\
\hline & & Mean & $\pm \mathrm{SD}$ & Mean & $\pm \mathrm{SD}$ & Mean & $\pm \mathrm{SD}$ & \\
\hline \multirow{4}{*}{$\begin{array}{l}\text { Total Motility } \\
\text { (\%) }\end{array}$} & DO & $67.9^{\text {Aa }}$ & 12.4 & $24.9^{\mathrm{Ba}}$ & 20.5 & $35.3^{\mathrm{Ba}}$ & 24.6 & 0.001 \\
\hline & D2 & $36.6^{\mathrm{Ab}}$ & 18.1 & $8.4^{\mathrm{Bb}}$ & 10.0 & $17.9^{\mathrm{ABb}}$ & 15.7 & 0.004 \\
\hline & D4 & $26.1^{\mathrm{Ab}}$ & 13.6 & $6.4^{\mathrm{Bb}}$ & 8.7 & $9.1^{\mathrm{Bb}}$ & 8.9 & 0.003 \\
\hline & P-value & \multicolumn{2}{|c|}{$<0,001$} & \multicolumn{2}{|c|}{0,006} & \multicolumn{2}{|c|}{0,001} & \\
\hline \multirow{4}{*}{$\begin{array}{c}\text { Progressive } \\
\text { Motility (\%) }\end{array}$} & DO & $31.9^{\mathrm{Aa}}$ & 10.2 & $12^{\mathrm{Ba}}$ & 13.0 & $17.6^{\mathrm{ABa}}$ & 15.8 & 0.019 \\
\hline & D2 & 13.9 Aab & 6.7 & $3.1^{\mathrm{Bb}}$ & 4.2 & $6.4^{\mathrm{Bab}}$ & 5.7 & 0.003 \\
\hline & D4 & $9.6^{\mathrm{Ab}}$ & 5.5 & $2.1^{\mathrm{Bb}}$ & 3.0 & $2.5^{\mathrm{Bb}}$ & 3.2 & 0.002 \\
\hline & P-value & \multicolumn{2}{|c|}{$<0,001$} & \multicolumn{2}{|c|}{0,018} & \multicolumn{2}{|c|}{0,005} & \\
\hline \multirow{4}{*}{$\begin{array}{c}\text { Fast sperm } \\
(\%)\end{array}$} & DO & $51^{\mathrm{Aa}}$ & 16.3 & $19.1^{\mathrm{Ba}}$ & 17.3 & $26.6^{\mathrm{Ba}}$ & 21.9 & 0.007 \\
\hline & D2 & $28.9^{A b}$ & 17.2 & $6.2^{\mathrm{Bb}}$ & 7.7 & $14.6^{\text {ABab }}$ & 13.0 & 0.009 \\
\hline & D4 & $20^{\mathrm{Ab}}$ & 12.7 & $5.1^{\mathrm{Bb}}$ & 7.1 & $6.1 A^{B b}$ & 6.2 & 0.009 \\
\hline & P-value & \multicolumn{2}{|c|}{$<0,001$} & \multicolumn{2}{|c|}{0,010} & \multicolumn{2}{|c|}{0,004} & \\
\hline \multirow{4}{*}{ VAP ( $\mu \mathrm{m} / \mathrm{s})$} & DO & $69.8^{\text {Аa }}$ & 16.4 & $70^{\mathrm{Aa}}$ & 20.9 & $71.5^{\text {Аа }}$ & 19.3 & 0.954 \\
\hline & D2 & $69.1^{\mathrm{Aa}}$ & 13.8 & $45.7^{\mathrm{Aa}}$ & 30.0 & $63.2^{\mathrm{Aa}}$ & 27.5 & 0.146 \\
\hline & D4 & $68.8^{\mathrm{Aa}}$ & 10.4 & $43.1^{\mathrm{Aa}}$ & 38.3 & $59.6^{\mathrm{Aa}}$ & 28.4 & 0.707 \\
\hline & P-value & \multicolumn{2}{|c|}{0,939} & \multicolumn{2}{|c|}{0,097} & \multicolumn{2}{|c|}{0,412} & \\
\hline \multirow{4}{*}{ VSL ( $\mu \mathrm{m} / \mathrm{s})$} & DO & $50.6^{\mathrm{Aa}}$ & 8.2 & $46.7^{\mathrm{Aa}}$ & 8.8 & $52.4^{\mathrm{Aa}}$ & 15.4 & 0.779 \\
\hline & D2 & $47.5^{\mathrm{Aa}}$ & 6.5 & $31.7^{\mathrm{Aa}}$ & 20.3 & $41.8^{\mathrm{Aa}}$ & 17.7 & 0.163 \\
\hline & D4 & $47.2^{\mathrm{Aa}}$ & 5.5 & $28.7^{\mathrm{Aa}}$ & 25.7 & $36.5^{\mathrm{Ab}}$ & 16.5 & 0.294 \\
\hline & P-value & \multicolumn{2}{|c|}{0,406} & \multicolumn{2}{|c|}{0,053} & \multicolumn{2}{|c|}{0,048} & \\
\hline
\end{tabular}

continue... 
contuation...

\begin{tabular}{|c|c|c|c|c|c|c|c|c|}
\hline \multirow{4}{*}{$\mathrm{VCL}(\mu \mathrm{m} / \mathrm{s})$} & DO & $136.6^{\text {Аа }}$ & 29.3 & $149.1^{\text {Аа }}$ & 40.8 & $148.9^{\text {Аа }}$ & 33.5 & 0.691 \\
\hline & D2 & $141.4^{\mathrm{Aa}}$ & 28.0 & $100.2^{\mathrm{Aa}}$ & 71.4 & $135.3^{\text {Aa }}$ & 58.9 & 0.464 \\
\hline & D4 & $141.2^{\text {Аа }}$ & 23.6 & $98.1^{\mathrm{Aa}}$ & 82.8 & $135.1^{\mathrm{Aa}}$ & 72.1 & 0.053 \\
\hline & P-value & \multicolumn{2}{|c|}{0,987} & \multicolumn{2}{|c|}{0,141} & \multicolumn{2}{|c|}{0,733} & \\
\hline \multirow{4}{*}{$\mathrm{ALH}(\mu \mathrm{m} / \mathrm{s})$} & Do & $6.1^{\mathrm{Aa}}$ & 0.8 & $6.1^{\mathrm{Aa}}$ & 1.1 & $6.8^{\mathrm{Aa}}$ & 1.3 & 0.390 \\
\hline & D2 & $2.6^{\mathrm{Aa}}$ & 49.2 & $4.7^{\mathrm{Aa}}$ & 3.9 & $6.4^{\mathrm{Aa}}$ & 2.7 & 0.191 \\
\hline & D4 & $7.2^{\mathrm{Aa}}$ & 1.1 & $3.5^{\mathrm{Aa}}$ & 3.8 & $6.4^{\mathrm{Aa}}$ & 2.7 & 0.160 \\
\hline & P-value & \multicolumn{2}{|c|}{0,417} & \multicolumn{2}{|c|}{0,104} & \multicolumn{2}{|c|}{0,839} & \\
\hline \multirow{4}{*}{ STR (\%) } & Do & $75^{\mathrm{Aa}}$ & 5.6 & $71.4^{\mathrm{Aa}}$ & 10.0 & $74.8^{\mathrm{Aa}}$ & 4.0 & 0.523 \\
\hline & D2 & $66.7^{\mathrm{Aa}}$ & 15.3 & $53.3^{\mathrm{Aa}}$ & 34.7 & $59^{A b}$ & 24.2 & 0.390 \\
\hline & D4 & $70.1^{\mathrm{Aa}}$ & 5.2 & $42.3^{\mathrm{Aa}}$ & 35.2 & $57.3^{A b}$ & 24.5 & 0.167 \\
\hline & P-value & \multicolumn{2}{|c|}{0,503} & \multicolumn{2}{|c|}{0,054} & \multicolumn{2}{|c|}{0,043} & \\
\hline \multirow{4}{*}{ LIN (\%) } & DO & $39.6^{\mathrm{Aa}}$ & 3.1 & $35.1^{\text {Aa }}$ & 8.3 & $36.9^{\mathrm{Aa}}$ & 3.6 & 0.284 \\
\hline & D2 & $42.4^{\mathrm{Aa}}$ & 13.7 & $30^{\mathrm{Aa}}$ & 27.4 & $28.4^{\mathrm{Aa}}$ & 11.8 & 0.068 \\
\hline & D4 & $36.8^{\mathrm{Aa}}$ & 6.6 & $19.5^{\mathrm{Aa}}$ & 17.5 & $28.9^{\mathrm{Aa}}$ & 13.6 & 0.413 \\
\hline & P-value & \multicolumn{2}{|c|}{0,450} & \multicolumn{2}{|c|}{0,257} & \multicolumn{2}{|c|}{0,052} & \\
\hline \multirow{4}{*}{ WOB (\%) } & DO & $50.9^{\mathrm{Aa}}$ & 2.9 & $46.5^{\mathrm{Aa}}$ & 6.3 & $47.6^{\mathrm{Aa}}$ & 2.9 & 0.126 \\
\hline & D2 & $48.9^{\mathrm{Aa}}$ & 4.1 & $37.4^{\mathrm{Aa}}$ & 27.4 & $40.9^{\mathrm{Aa}}$ & 16.6 & 0.098 \\
\hline & D4 & $49.1^{\mathrm{Aa}}$ & 4.0 & $27.14^{\mathrm{Aa}}$ & 23.5 & $39.9^{\mathrm{Aa}}$ & 17.3 & 0.073 \\
\hline & P-value & \multicolumn{2}{|c|}{0,599} & \multicolumn{2}{|c|}{0,157} & \multicolumn{2}{|c|}{0,235} & \\
\hline
\end{tabular}

Capital letters show a difference between the total semen groups (Total), centrifuged at 600G/10 min (G2) and filtered through filtration (Sperm-filter ${ }^{\circledR}$ (G3). Lowercase letters show a difference between cooling times (D0, D2, D4). Bold values demonstrate hyperactive behavior.

\section{Table 2}

Lipid peroxidation (TBARS) results of boars' semen. Total semen samples (G1), centrifuged at $600 \mathrm{~g} / 10$ min (G2) and filtered through Sperm-filter ${ }^{\circledR}$ (G3) at three moments: fresh (D0) and refrigerated for $48 \mathrm{~h}$ (D2) and $96 \mathrm{~h}(\mathrm{D} 4)$ at $17^{\circ} \mathrm{C}$

\begin{tabular}{|c|c|c|c|c|c|c|c|c|}
\hline \multirow{2}{*}{ TBARS } & & \multicolumn{2}{|c|}{ Total (G1) } & \multicolumn{2}{|c|}{ Centrifuged (G2) } & \multicolumn{2}{|c|}{ Filtered (G3) } & \multirow[b]{2}{*}{ P-value } \\
\hline & Moment & Mean & $\pm \mathrm{SD}$ & Mean & $\pm \mathrm{SD}$ & Mean & $\pm \mathrm{SD}$ & \\
\hline \multirow{4}{*}{$\begin{array}{l}\text { TBAR SP } \\
\text { (mmol de } \\
\text { MDA/ml) }\end{array}$} & DO & $8.1^{\mathrm{Aa}}$ & 5.2 & $3.9^{\mathrm{Ba}}$ & 2.1 & $2.9^{\mathrm{Ba}}$ & 0.9 & 0.011 \\
\hline & D2 & $7.4^{\mathrm{Aa}}$ & 4.2 & $2.4^{\mathrm{Ba}}$ & 1.6 & $2.7^{\mathrm{Aa}}$ & 0.9 & 0.024 \\
\hline & D4 & $6.4^{\mathrm{Aa}}$ & 4.0 & $1.7^{\mathrm{Ba}}$ & 1.1 & $3.8^{\mathrm{Aa}}$ & 2.9 & 0.008 \\
\hline & P-value & \multicolumn{2}{|c|}{0,690} & \multicolumn{2}{|c|}{0,125} & \multicolumn{2}{|c|}{0,366} & \\
\hline \multirow{4}{*}{$\begin{array}{l}\text { TBAR SG } \\
\text { (mmol de } \\
\text { MDA/ml) }\end{array}$} & Do & $5.6^{\mathrm{Aa}}$ & 2.4 & $3.7^{\text {Aa }}$ & 1.3 & $3.1^{\mathrm{Ba}}$ & 15,8 & 0.029 \\
\hline & D2 & $7.5^{\mathrm{Aa}}$ & 4.1 & $3.7^{\mathrm{Ba}}$ & 1.8 & $4.2^{\mathrm{Aa}}$ & 2.1 & 0.030 \\
\hline & D4 & $7.6^{\mathrm{Aa}}$ & 3.4 & $5.0^{\mathrm{Aa}}$ & 2.9 & $4.9^{\mathrm{Aa}}$ & 3.9 & 0.103 \\
\hline & P-value & \multicolumn{2}{|c|}{0,290} & \multicolumn{2}{|c|}{0,180} & \multicolumn{2}{|c|}{0,459} & \\
\hline
\end{tabular}

TBARS SP- spontaneous reaction; TBARS SG- induced reaction. Capital letters show a difference between the total semen groups (G1), centrifuged at 600G/10 min (G2) and filtered through sperm filter ${ }^{\circledR}(G 3)$.

Lowercase letters show a difference between cooling times (D0, D2, D4). 
The best kinetic parameters shown by the fresh semen emphasizes the deleterious effects of time and temperature on the sperm cells viability. Damage to sperm cells as a result of a drop in temperature due to the cooling process, osmotic shock, oxidative stress and membrane injuries have been demonstrated as harmful to sperm motility (Wasilewska \& Fraser, 2017).

The total semen aliquot (G1) showed the best results of all kinetic parameters when compared to samples submitted to centrifugation (G2) and filtration (G3). However all the motility results were lower than those demanded by the Colégio Brasileiro de Reprodução Animal CBRA (2013), which allows the use of boar sperm in reproduction biotechnologies when fresh with $70 \%$ of mobile sperm cells, while for the refrigerated sperm $50 \%$ of the spermatozoa must have motility ward.

Although seminal plasma serves as a mean of transporting sperm through the female's reproductive tract (Juyena \& Stelletta, 2012), many studies have concentrated efforts to better understanding of its action on sperm cells (Li et al., 2018; Luna et al., 2017; Yeste, 2016). Bergstein-Galan et al. (2017) did not observe benefits of seminal plasma in the longevity of sheep sperm refrigerated at $5^{\circ} \mathrm{C}$. However, in boars, the absence of seminal plasma can improve the fertility rates of refrigerated semen (Pavaneli et al.,2019), reducing the occurrence of sperm lesions that interfere in cell preservation. In addition, premature capacitation was noted in the sperm cells submitted to the seminal plasma, which leads to sperm with stimulated motility, increasing ROS production, and inducing membrane and acrosome injuries (Aitken \& Clarkson, 1988).
In order to reduce the occurrence of sperm lesions that interfere with cell preservation, centrifugation of the boar ejaculate in a refrigerated centrifuge at $15^{\circ} \mathrm{C}$ has been recommended (Bianchi et al., 2008). However, in the present study, a non-refrigerated centrifuge was used in accordance with another study performed to evaluate the usefulness of the Sperm Filter ${ }^{\circledR}$ usefulness in horses (Ramires et al., 2013).

Separation of porcine seminal plasma through filtration can be useful in the absence of a refrigerated centrifuge, which may reduce the damage to sperm cells by preventing the temperature from rising during rotation. The beneficial effect of filtration was observed in horses, in which the ejaculate filtration provided a higher sperm recovery rate than centrifugation (89\% vs $81 \%$ ) with similar sperm kinetics (total motility $=51 \%$; progressive motility $=21.8 \%$ ) and plasma membrane integrity (plasma membrane integrity $=51.0 \%$ ) after 24 hours of refrigeration (Pedrazzi et al., 2012).

The results of total and progressive motility, and fast sperm obtained with the Sperm-filter (G3) when compared to total semen (G1) might have been negatively influenced by the small formation of foam during processing. The formation of air bubbles in contact with sperm cells can potentially affect the protein integrity of the membrane by denaturation and impaired mitochondrial function (Menegat et al., 2017; Ribeiro, Moroni, \& Menegat, 2016; Sobolewski, Kandel, \& Eckmann, 2012). Despite the foam formation during the filtration, the centrifugation process did cause major damages to the sperm cell, when compared with centrifugation. 
Although the total semen aliquot (G1) refrigerated for up to 96 hours yielded superior sperm kinetics results, it showed higher lipid peroxidation due to the presence of seminal plasma, similarly to other studies ( $\mathrm{Li}$ et al., 2018; Wasilewska \& Fraser, 2017). Based on this assumption and in order to concentrate sperm cells, the Sperm Filter ${ }^{\circledR}$ could be used to separate seminal plasma with less occurrence of oxidative stress, especially when the semen is assigned for cryopreservation purposes.

Considering hyperactivation of sperm cells, conflicting results have been demonstrated among some studies. In the present one, comparisons between fresh and refrigerated centrifuged and filtered semen revealed hyperactive behavior of sperm cells (D2 and D4), since the refrigerated sperm showed higher values of ALH and lower values of LIN, STR and WOB as proposed by Pavaneli et al. (2019), (G2 D2: ALH= 4,7 $\mu \mathrm{m} / \mathrm{s}$, STR= $53,3 \%, \mathrm{LIN}=30 \%$ and $\mathrm{WOB}=37,4 \% ; \mathrm{G} 2 \mathrm{D} 4$ $\mathrm{ALH}=3,5 \mu \mathrm{m} / \mathrm{s}, \mathrm{STR}=42,3 \%, \mathrm{LIN}=19,5 \%$ and WOB $=27,14 \% ;$ G3 D2: ALH= 6,4 $\mu \mathrm{m} / \mathrm{s}, \mathrm{STR}=$ $59 \%, \mathrm{LIN}=28,4 \%$ and $\mathrm{WOB}=40,9 \%$; G3 D4: $\mathrm{ALH}=46,4 \mu \mathrm{m} / \mathrm{s}, \mathrm{STR}=57,3 \%, \mathrm{LIN}=28,9 \%$ and WOB $=39,9 \%$ ), which is similar to the study by Muiño, Rivera, Rigau, Rodriguez-Gil and Peña (2008), in which swine semen was refrigerated at $5^{\circ} \mathrm{C}$. On the other hand, no influence of seminal plasma on sperm hyperactivation was shown by Pavaneli et al. (2019), who actually observed that cooling time decreased the occurrence of hyperactivated behavior. Sperm hyperactivation was also noticed after thawing semen samples at $37^{\circ} \mathrm{C}$ (Hurtado de Llera et al., 2018). The increase in semen temperature induces the release of intracellular calcium stores present in sperm. This effect of hyperactivation might also have occurred in the current study in samples refrigerated at $17^{\circ} \mathrm{C}$ that were heated to $37^{\circ} \mathrm{C}$ for kinetic analysis in the present study.

Higher efficiency in bovine embryo production was found using filtered cryopreserved semen compared to centrifuged semen ( $24 \%$ vs $18 \%$, respectively) (Campanholi et al., 2017). In addition, advantages of horse semen filtration in decreasing membrane lesions $163 \%$ of intact membrane in filtrated samples vs $41 \%$ of intact sperm membrane in the centrifuged samples) and bacterial growth was noticed by Alvarenga et al. (2012), even though no differences in kinetic variables were found between centrifuged and filtered samples. This is the first study to report the use of the Sperm-filter ${ }^{\circledR}$ in the boar ejaculate.

The seminal plasma separation seemed to be beneficial for decreasing the production of ROS in refrigerated swine semen. However, the absence of seminal plasma generated a hyperactive behavior in the sperm cells. Whether this behavior can be harmful to fertility rates in swine warrants further investigation is required. In addition, future studies may test other extenders and refrigeration curves in order to minimize the occurrence of a hyperativated pattern of sperm after refrigeration.

\section{Conclusion}

Our results concluded that the sperm filtration technique may be an easier and cheaper method in comparison to the centrifugation, and so can be used as a viable and efficient alternative for separation of seminal plasma in swine. 


\section{Acknowledgements}

To Botupharma -Biotecnologia Animal for providing us the Sperm-filter ${ }^{\circledR}$. And to CAPES for granting the postgraduates scholarship.

\section{Conflict of Interest}

The authors declare no conflicts of interest.

\section{Declaration of Funding statement}

This research did not receive any specific funding.

\section{References}

Aitken, R. J., \& Clarkson, J. S. (1988). Significance of Reactive Oxygen Species and Antioxidants in Defining the Efficacy of Sperm Preparation Techniques. Journal of Andrology, 9(6), 367-376. doi: 10.1002/ j.1939-4640.1988.tb01067.x

Albuquerque, R. S., Morais, R., Reis, A. N., Miranda, M. S., Dias, E. A. R., Monteiro, F. M., ... Gimenes, L. U. (2017). Comparison of two methods of seminal plasma removal on buffalo (Bubalus bubalis) sperm cryopreservation. Reproduction in Domestic Animals, 52(5), 905-910. doi: doi.org/10.1111/rda.12992

Alkmin, D. V, Perez-patiño, C., Barranco, I., Parrilla, I., Vazquez, J. M., Martinez, E. A., ... Roca, J. (2014). Cryobiology Boar sperm cryosurvival is better after exposure to seminal plasma from selected fractions than to those from entire ejaculate $\mathrm{q}$. Cryobiology, 69(2), 203-210. doi: 10.10 16/j.cryobiol.2014.07.004

Alvarenga, M A, Melo, C. M., Magalhães, L. C. O., \& Papa, F. O. (2010). A new method to concentrate equine sperm. Animal Reproduction Science, 121(S), 186-187. doi: 10.1016/j.anireprosci.2010.04.142

Alvarenga, Marco Antonio, Papa, F. O., Carmo, M. T., Kievitsbosch, T., Castro Chaves, M. M. B., \& Ramires Neto, C. (2012). Methods of Concentrating Stallion Semen. Journal of Equine Veterinary Science, 32(8), 424429. doi: 10.1016/j.jevs.2012.06.003

Awda, B. J., Mackenzie-Bell, M., \& Buhr, M. M. (2009). Reactive Oxygen Species and Boar Sperm Function1. Biology of Reproduction, 81(3), 553-561. https://doi. org/10.1095/biolreprod.109.076471

Barreiros, A. L. B. S., David, J. M., \& David, J. P. (2006). Estresse oxidativo: Relação entre geração de espécies reativas e defesa do organismo. Quimica Nova, 29(1), 113-123. doi: 10.1590/s0100-40422006000100021

Bergstein-Galan, T. G., Weiss, R. R., Bertol, M. A. F., Abreu, A. C. M. R., Busato, E., Kozicki, L. E., \& Bicudo, S. D. (2017). Quality and fertility of frozen ovine spermatozoa from epididymides stored at room temperature $\left(18-25^{\circ} \mathrm{C}\right)$ for up to $48 \mathrm{~h}$ post mortem. Theriogenology, 96(17), 69-75. doi: 10.10 16/j.theriogenology.2017.04.001

Bianchi, I., Calderam, K., Maschio, É. F., Madeira, E. M., da Rosa Ulguim, R., Corcini, C. D., ... Corrêa, M. N. (2008). Evaluation of amides and centrifugation temperature in boar semen cryopreservation. Theriogenology, 69(5), 632-638. doi: 10. 1016/j.theriogenology.2007.11.012 
Campanholi, S. P., Monteiro, F. M., Ribeiro Dias, E. A., Mercadante, M. E. Z., de Paz, C. C. P., Dell'Aqua Junior, J. A., ... Garcia, J. M. (2017). Effect of seminal plasma removal before cryopreservation of bovine semen obtained by electroejaculation on semen quality and in vitro fertility. Theriogenology, 89(16), 114-121. doi: 10. 1016/j.theriogenology.2016.10.008

CBRA. (2013). Manual para exame andrológico e avaliação de sêmen animal. (3rd ed.). Belo Horizonte: Colégio Brasileiro de Reprodução Animal.

Gadea, J., Martínez-Miró, S., Decuadro-Hansen, G., \& Matás, C. (2006). 92 Evaluation of Boar Sperm Functionality After a Cushioned Centrifugation Technique. Reproduction, Fertility and Development, 18(2), 154. doi: 10.1071/rdv18n2ab92

Gómez-Fernández, J., Gómez-Izquierdo, E.ı Tomás, C.,Mocé, E.,\&Mercado, E. de.(2012). Effect of different monosaccharides and disaccharides on boar sperm quality after cryopreservation. Animal Reproduction Science, 133(1-2), 109-116. doi: 10.1016/j. anireprosci.2012.06.010

Hallap, T., Ha, M., Larsson, B., \& Rodriguezmartinez, H. (2004). Does cleansing of frozen-thawed bull semen before assessment provide samples that relate better to potential fertility? Theriogenology, 62 (04), 702-713. doi: 10. 1016/j.theriogenology.2003.11.017

Hancock, G. L. (1959). The morphologic characteristics of spermatozoa and fertility. Internacional Journal of Fertility, 4, 347-359.

Hurtado de Llera, A., Gil, M. C., Bragado, M. J., Martin-Hidalgo, D., Garcia-Marin,
L. J., \& Perez, C. J. (2018). Boar sperm hyperactivated motility is induced by temperature via an intracellular calciumdependent pathway. Reproduction, Fertility and Development, 30(11), 1462. doi: $10.1071 /$ rd17549

Juyena, N. S., \& Stelletta, C. (2012). Seminal Plasma: An Essential Attribute to Spermatozoa. 33(4), 536-551. doi: 10.21 64/jandrol.110.012583

Larentis, G. R., Camozzato, G. C., Bastos, H. B. A., Gregory, R. M., \& Mattos, R. C. (2018). Equine Sperm Selection by Synthetic Membrane Filter. Journal of Equine Veterinary Science, 63 (17), 69-73. doi: 10. 1016/j.jevs.2018.01.013

Li, J., Roca, J., Pérez-patiño, C., Barranco, I., \& Martinez, E. A. (2018). Is boar sperm freezability more intrinsically linked to spermatozoa than to the surrounding seminal plasma? Animal Reproduction Science, 195(5), 30-37. doi: 10.1016/j. anireprosci.2018.05.002

Luna, C., Yeste, M., Rivera Del Alamo, M. M., Domingo, J., Casao, A., Rodriguez-Gil, J. E., ... Muiño-Blanco, T. (2017). Effect of seminal plasma proteins on the motile sperm subpopulations in ram ejaculates. Reproduction, Fertility and Development, 29(2), 394-405. doi: 10.1071/RD15231

Menegat, M. B., Mellagi, A. P. G., Bortolin, R. C., Menezes, T. A., Vargas, A. R., Bernardi, M. L., ... Bortolozzo, F. P. (2017). Sperm quality and oxidative status as affected by homogenization of liquid-stored boar semen diluted in short- and longterm extenders. Animal Reproduction Science, 179(17), 67-79. doi: 10.1016/j. anireprosci.2017.02.003 
Muiño, R., Rivera, M. M., Rigau, T., RodriguezGil, J. E., \& Peña, A. I. (2008). Effect of different thawing rates on post-thaw sperm viability, kinematic parameters and motile sperm subpopulations structure of bull semen. Animal Reproduction Science, 109(1-4), 50-64. doi: 10.1016/j. anireprosci.2007.11.028

Nogueira, B. G., Bitencourt, J. L., Sampaio, B. F. B., Bender, E. S. C., Costa e Silva, E. V., \& Zúccari, C. E. S. N. (2014). Peroxidação lipídica e agentes antioxidantes no sêmen de mamíferos. Revista Electronica de Veterinaria, 15(1), 1-15. Recuperado de https://www.veterinaria.org/revistas/ redvet/n010114

Okazaki, T., Abe, S., Yoshida, S., \& Shimada, M. (2009). Seminal plasma damages sperm during cryopreservation, but its presence during thawing improves semen quality and conception rates in boars with poor post-thaw semen quality. Theriogenology, 71(9), 491-498. doi: 10. 1016/j.theriogenology.2008.08.014

Pavaneli, A.P.P., Passarelli, M. daS., de Freitas, F. V., Ravagnani, G. M., Torres, M. A., Martins, S. M. M. K., ... de Andrade, A. F. C. (2019). Removal of seminal plasma prior to liquid storage of boar spermatozoa: A practice that can improve their fertilizing ability. Theriogenology, 125(19), 79-86. doi: 10. 1016/j.theriogenology.2018.10.020

Pedrazzi, C., Monteiro, G. A., Ramires Neto, C., Soares, R. F., Papa, F. O., Dell'aqua, J. A., \& Alvarenga, M. A. (2012). Effect of removing seminal plasma using a sperm filter on the viability of refrigerated stallion semen. Journal of Equine Veterinary Science, 33(1), 40-43. doi: 10.1016/j. jevs. 2012.04.008
Perez-patiño, C., Barranco, I., Parrilla, I., Valero, M. L., Martinez, E. A., Rodriguez-martinez, H., \& Roca, J. (2016). Characterization of the porcine seminal plasma proteome comparing ejaculate portions. Journal of Proteomics, 142(16), 15-23. doi: 10.10 16/j.jprot.2016.04.026

Placer, Z. A., Cushman, L. L., \& Johnson, B. C. (1966). Estimation of product of lipid peroxidation (malonyl dialdehyde) in biochemical systems. Analytical Biochemistry, 16(2), 359-364. doi: 10.10 16/0003-2697(66)90167-9

Ramires, C., Augusto, G., Fatima, R., Pedrazzi, C., Antonio, J., Ozanan, F., \& Antonio, M. (2013). Effect of removing seminal plasma using a sperm filter on the viability of refrigerated stallion semen. Journal of Equine Veterinary Science, 33(1), 40-43. doi: 10.1016/j.jevs.2012.04.008

Ribeiro, C. D. V., Moroni, J. L., \& Menegat, M. B. (2016). Redalyc. The influence of air contact on the quality of extended boar semen. Acta Scientiae Veterinariae, 44(1), 1-7. doi: 10.22456/1679-9216.81300

Saravia, F., Wallgren, M., Johannisson, A., Calvete, J. J., Sanz, L., \& Pen, F. J. (2009). Exposure to the seminal plasma of different portions of the boar ejaculate modulates the survival of spermatozoa cryopreserved in MiniFlatPacks. Theriogenology, 71(9), 662-675. doi: 10. 1016/j.theriogenology.2008.09.037

Sobolewski, P., Kandel, J., \& Eckmann, D. M. (2012). Air bubble contact with endothelial cells causes a calcium-independent loss in mitochondrial membrane potential. Plos One, 7(10), 1-8. doi: 10.1371/journal. pone.0047254 
Souza, F. C., Melanda, C. A. A., Zandonadi, F., Morotti, F., Martins, M. I. M., Silva, C. A., \& Seneda, M. M. (2013). Análise do movimento espermático suíno submetido a refrigeração por até 96 horas em diferentes meios de diluição. $22^{\circ}$ Encontro Anual de Iniciação Científica (EA/C) e $3^{\circ}$ Encontro Anual de Iniciação Tecnológica e Inovação (EAITI), Londrina, PR, Brasil 22, 3.

Wasilewska, K., \& Fraser, L. (2017). Boar variability in sperm cryo-tolerance after cooling of semen in di ff erent long-term extenders at various temperatures. Animal Reproduction Science, 185(8), 161-173. doi: 10.1016/j.anireprosci.2017.08.016

Yeste, M. (2016). Theriogenology Sperm cryopreservation update: Cryodamage, markers, and factors affecting the sperm freezability in pigs. Theriogenology, 85(1), 47-64. doi: 10.1016/j.theriogenology.20 15.09.047 
